\title{
Probe into the Main Contents and Cultivation Path of Russian National Spirit*
}

\author{
Junsheng Zhang \\ School of Marxism \\ Dalian University of Technology \\ Department of Humanities \\ Dalian University \\ Dalian, China
}

\author{
Yanying Fei \\ Department of Humanities and Social Sciences \\ Dalian University of Technology \\ Dalian, China
}

\begin{abstract}
The Russian national spirit is formed by Russia in the process of long-term survival and development, and it is a psychological state accepted and adhered to by members of the Russian nation. The Russian national spirit includes the patriotic sentiments dedicated to the country, the value orientation of the supremacy of collective interests, the fighting spirit of militancy, the sense of perseverance, and the Messianic consciousness based on a rich religious background. In the process of cultivating the Russian national spirit, it has formed the national spiritual cultivation path system which has combined government leadership, school curriculum teaching, family basic education, religious culture education and social practice together. It is possible to learn from the experience of Russian regarding cultivating the national spirit, comprehensively strengthening national culture education, enhancing cultural self-confidence, taking patriotism as the core position of national spirit cultivation, and multidimensional cooperation to promote national spirit education in the process of cultivating the Chinese national spirit in the new era.
\end{abstract}

Keywords-Russia; national spirit; cultural self-confidence; patriotism; messiah

\section{INTRODUCTION}

The Russian nation is a great nation in the forest of the nations of the world. Its development has a very important impact on the world history and the progress of civilization. The reason why the Russian nation can win challenges, develop and grow, and achieve world-renowned achievements in its survival process is mainly because the Russian national spirit rooted in the hearts of its nationalities for thousands of years. The Russian national spirit is formed in the long-term survival and development process. It is the psychological state accepted and adhered to by the Russian national members and also the spirit reflection of the Russian national social economy, historical traditions, lifestyles and

*Fund: National social science fund project: research on cultivation of national spirit from the perspective of cultural confidence strategic level (15BKS129) Liaoning province social science planning fund project (L17BSZ002). Study on cultivation of college students' national spirit from the perspective of cultural self-confidence; Dalian social science association project (2019dlskyb166) study on effective ways of cultivating the spirit of college students in Liaoning in the new era. geographical environment. [1] The Russian national spirit expresses the unique ethnic interests, hobbies, character, temperament, abilities and values through special expressions such as national language, lifestyle, literature and art, religious beliefs, aesthetic tastes and emotional conversion. Therefore, a comprehensive examination of the basic content of the Russian national spirit and the cultivation path will have important reference value for China to strengthen the cultivation of the Chinese national spirit in the new historical direction.

\section{Main Content OF THE RUSSiAn NATIONAL SPIRIT}

The natural environment of the Russian nation's natural environment has created its unique national character. The process of Russian historical development has been influenced by the alternation of Eastern and Western cultures, which has injected multiple elements into the formation and development of the Russian national spirit. These characteristics and elements have deeply influenced the Russian national spirit and endowed it with profound content

\section{A. The Patriotic Feelings Dedicated to the Country}

Patriotism is the core of the Russian national spirit. It can be seen in the context of the development of Russian national history that the Russians of each era have shown their strong patriotic enthusiasm. Whether it is a war or a peaceful era, the spirit of patriotism is the absolute spiritual pillar supporting the survival and development of the Russian nation. This kind of patriotic sentiment stems from the nomadic characteristics of the Russian ancestors, the Eastern Slavs. They have a strong sense of existence and can do everything they can to protect their country's security. This sentiment is also derived from the territorial consciousness of the most extensive ethnic group and always maintains a high degree of vigilance for the safety of the country. The patriotic sentiments of the Russian nation also originated from the feelings of the motherland after the baptism of the war, whether it was the history of humiliation that was once conquered by the Mongols in ancient times, or the subsequent war against Napoleon's invasion, or the resistance of Hitler's Nazi group. After the baptism of the Great Patriotic War, the Russian nation has more clearly 
was nurtured a spirit of toughness and indomitable enterprising consciousness in the history of this struggle. Under the support of this unyielding spirit, the Russian nation understands the forbearance, be confident for the future, have the courage to transcend the difficulties, gather strength in the hard environment and the hard work of forging ahead, and finally realize the development and transcendence of the nation. From a historical and realistic point of view, no matter how much humiliation has been left in history, no matter how many challenges remain in the future, the tough and unyielding spirit of the Russian nation can lead the Russian people to win their due dignity and ultimate victory.

\section{E. Religious Messianic Consciousness}

Russia is a religiously dignified nation. The Orthodox Church has a profound influence on the formation and development of Russian culture. The Russian national spirit also contains a large number of religious elements, the most prominent of which is the Messianic consciousness. The Messianic consciousness is one of the important ethnic characteristics of the Russian nation and a common national identity of the Russians. [5] The Messianic consciousness of Russia consists of three levels: on the religious level, Russia claims to be the heir and savior of the Orthodox Church; at the spiritual level it considers that the national thought is the best weapon to save the world; on the political level, Russia tries to liberate all mankind. [6] It not only emphasizes the authenticity and mission of its own nation in the context of religion, but also includes the consciousness and world mission of the Russian nation. On the practical level, the Russian people are cheerful, helpful and hospitable. The mutual help spirit and world mission in the consciousness of the Messiah Consciousness can indeed make people feel the sense of responsibility and mission of the great nation.

\section{CUltivation PATH OF RUSSiAn NATIONAL SPIRIT}

Although the Russian nation experienced development bottlenecks and major twists and turns in different historical periods, under the support and encouragement of the national spirit with patriotism as its core, the Russian nation can still resurrect in the predicament and move forward. The history of the development of the Russian nation reflects the important value of the Russian national spirit. The Russian nation also attaches great importance to the cultivation of the Russian national spirit and has formed a breeding path with Russian national style.

\section{A. Government Policy Leading the Guarantee That the Russian National Spirit Cultivation Has Rules to Follow}

The Russian national spiritual education during the Soviet period was based on government-led education. The Soviet government emphasized the use of MarxismLeninism and communist views to influence the people and cultivate the people into citizens with communist beliefs and ideals and morality. The government has successively introduced policies to implement political education, labor education and moral education for citizens. During a period of time, the Soviet government intensified the promotion of 
national spiritual education, and the domestic ideological understanding was highly unified, condensing a strong spiritual force. After the disintegration of the Soviet Union, Russia's domestic political, economic, cultural and social crises were highlighted, and the Russian national spirit was extremely low. A series of policy measures from Russian Federal Government to reinvigorate the Russian national spirit have been introduced successively. The strengthening of the Russian national spirit through the path led by the government policy has become the most prominent educational feature of the Russian Federation. At this stage, the Russian federal government has implemented policies and regulations to strengthen the cultivation of the national spirit. The government has successively promulgated the "Federal Law on the National Education Standards for General Education", the "Outline of the Citizens' Patriotic Education of the Russian Federation from 20016 to 20010", the "Russian Military Honor Day Law" and other laws and regulations, and implementation guidelines to create a good policy for the cultivation of national spirit.

\section{B. The Teaching of School Curriculum Has Laid the Basic Premise for the Cultivation of Russian National Spirit}

School curriculum teaching is the main path for the cultivation of Russian national spirit. The teaching of Russian school curriculum has been given a higher mission, which is to strengthen the deep national sentiment and build the most basic cognition of the national spirit. The main way is to infiltrate Russian cultural traditions and patriotic emotions through subtle influences in various courses and to carry out the cultivation of national spirit. The Russian education department has proposed a civic education reform program on the "multiple structure" to all sectors of society, that is, a cross-cut structural education program. Among them, the "horizontal structure" emphasizes that in the various courses offered by the school, the necessary patriotism and the education of the strong country must be carried out, and this kind of education is mainly based on the invisible education of infiltration, intended to let the students feel the deep national spirit and emotion of the Russian nation while learning the knowledge. The "longitudinal structure" refers to schools of different age structures that undertake different levels of national spiritual cultivation content, that is, each school must adopt different levels of acceptance of course materials according to the basic characteristics of students of different ages, using the targeted approach to conduct national spirit teaching activities in a hierarchical and phased manner. The classroom teaching of the Russian national spirit played a key and fundamental role in the cultivation of the national spirit, and strengthened the recognition and recognition of the national spirit by the student groups.

\section{Family Basic Education Enhances the Traditional Background of Russian National Spirit Cultivation}

The family is the most basic unit of society. The family is the starting point for the growth of members. The enlightenment of members' thoughts and the cognition of the motherland are closely related to the cultivation of the family. The members' initial patriotism, moral cultivation, and mode of thinking are all formed under the influence of the family. Russian family education has traditional characteristics. First, parents pay attention to the shaping of their children's moral character and are good at helping their children to establish correct values. Second, it is good at transferring Russian traditional culture and national history to children and enhancing their cultural identity. Third, they do well in guiding their children with their correct demonstrations. It is in the strong atmosphere of family education that Russian young people have established correct moral concepts in their growth and have also enhanced their recognition of the motherland and the nation. In recent years, the Russian ruling party has paid more attention to the role of family education in the cultivation of national spirit. In April 2010, the United Russia Party held a special meeting of "Family as the foundation of Russian patriotism education" and called on all the people to practice the concept "Respect for the elderly, respect for history, loyalty to the motherland and duties"[7], and in view of the predicament of the pressure on the family life in Russia, the federal government has also increased the protection and improved living conditions to enhance the effect of national spiritual education.

\section{Social Practice Activities Enhance the Realistic Effect of Russian National Spirit Cultivation}

The Russian government attaches great importance to cultivating the national spirit through the implementation of historical and cultural practices, and effectively relying on these existing historical and cultural resources to carry out practical education activities has greatly enhanced the effect of the Russian nation spirit. First, Russia is good at using the National Military Honor Day and National Day to carry out national spiritual cultivation activities. On every commemorative day, all levels of government in Russia will organize military parade or other commemorative activities to help the public feel the spirit of patriotism and enhance national sentiment. It is worth mentioning that the wedding of young Russians in the heroic cemetery has become a custom, allowing all the people present to accept the patriotism baptism while enjoying the wedding. Second, the rich cultural and artistic heritage of Russia can effectively promote the promotion and cultivation of the national spirit. Many Russian works of art contain a lot of national spiritual connotations. The Russian people often organize exhibitions of art exhibitions at various museums, and enjoy operas and ballets in concert halls and theaters. These cultural practices have strengthened the cultivation of the national spirit of the Russian people in a subtle way. Third, Russia has always attached importance to military mobilization and military experience. The Russian government introduced the "Defense Law", which specifically formulated relevant measures for military patriotism education for the Russian people, and allocated a large amount of funds for defense teaching and military experience activities. The rich social and historical resources and unique military experience activities have effectively cultivated the patriotism of the Russian people and greatly promoted the cultivation of the Russian national spirit. 


\section{ENLIGHTENMENT OF THE CULTIVATION OF RUSSIAN NATIONAL SPIRIT TO CHINA} Carrier of Russian National Spirit Cultivation

The Russian nation has a profound religious and cultural heritage. Religious culture is also an important part of Russian national culture. Religious and cultural education is of great significance to the cultivation of Russian national spirit. Former Russian President Dmitry Medvedev once said "The root of social morality lies in the religious tradition of the Russian people and lies in its humanitarian orientation." "The role of religious organizations in maintaining adolescent mental health and morality is undoubtedly very high." [8] In recent years, the Orthodox Church has played an increasingly important role in fostering the Russian national spirit. The main way for the church to nurture the national spirit is to use its affiliated seminary, church school, and worship school to spread patriotism and civic ethics to the general public. At the same time, Orthodox clubs have been established in various places to spread Russian traditional national culture and exchange Orthodox ideas. The club effectively assists the church in the dissemination of traditional culture and national spirit and becomes an important carrier of religious education. In 2009, the Ministry of Education of the Russian Federation requested 18 federal republics to conduct elective courses for the Orthodox Cultural Foundation for primary and secondary schools in China. The Orthodox culture has become an important cultural resource affecting the thinking of the Russian people and has become an important part of the cultivation of the Russian national spirit.

\section{F. All-media Propaganda Reports Have Expanded the Coverage of Russian National Spiritual Cultivation}

Media propaganda reports have important value for the cultivation of Russian national spirit. The mass media is considered to be the most educational carrier of the depth and influence of the society in today's society. With its rich content and outstanding timeliness, it can attract and influence the people. In the all-media era, the media has become more comprehensive and more prominent due to the development of the Internet. In the process of cultivating the Russian national spirit, the role played by various media has become increasingly prominent, and the coverage of national spiritual cultivation has also increased significantly. In recent years, the Russian federal government has attached great importance to the channel role of media propaganda and reporting in the process of cultivating the national spirit of the people, and has given a large amount of capital investment and personnel allocation, thus ensuring that the propaganda media can communicate to the public in a comprehensive, objective and proactive manner to foster the content of the national spirit. The mass media publicizes and reports on the national spirit, mainly promoting the basic values, good moral cultivation and correct ways of thinking, including not only the Russian national history, national major issues, but also heroic deeds and other positive energy. The content, as well as reporting and attacking the events and characters that undermine the national image and personal moral corruption, in order to cultivate the values and national spirit of the people from multiple angles.
General Secretary Xi Jinping pointed out at the 19th National Congress of the Communist Party of China: "After long-term efforts, socialism with Chinese characteristics has entered a new era, which is a new historical orientation for China's development." [9] Standing at a new historical starting point, facing the rapidly changing domestic and international environment, the development prospects are very bright and the challenges are still grim. In this context, whether it is to cope with the development difficulties at home and abroad, resist the intrusion of Western thoughts, or realize the Chinese dream of great rejuvenation of the Chinese nation, it is of vital importance to further promote and nurture the spirit of the Chinese nation. Russia is a recognized great nation in the world. The national spirits of the Chinese nation and the Russian have many similarities, and they shine with the rational brilliance together. Russia's experience in the cultivation of its national spirit is an important and useful reference for effectively improving the spiritual cultivation of the Chinese nation.

\section{A. Strengthening National Cultural Education in an All- round Way and Enhancing Cultural Self-confidence Is the Foundation for Strengthening the Cultivation of National Spirit}

The national spirit is the essence of national culture, the source of spiritual strength for the survival and development of the nation, and also the foundation of national culture confidence. In the process of cultivating the national spirit, Russia is good at effectively using various kinds of national strong history and era value to carry out educational activities are worth of reference. In this, the full use of the Russian National Day, such as the Victory Day of the Great Patriotic War and other historical commemorative days to carry out targeted patriotic education activities can effectively stimulate the patriotic enthusiasm of the entire nation and enhance national sentiment. The historical and memorial sites built for historical events and heroes all provide good material and cultural resources for cultivating the national spirit. At the same time, Russia's many culturally rich museums and exhibition halls, Russian ballet art and painting art are also highly accomplished. These cultural resources bear the task of cultivating national culture and carrying forward the national spirit. In addition, Russian national education also sublimates and leads the national spirit education through omnipresent cultivation of national culture, and infiltrates the national spirit into the national culture education of all ages in Russia.

\section{B. Persist in Placing Patriotism at the Core of the National Spirit Is the Principle of Strengthening the Cultivation of the National Spirit}

The patriotism that highlights the consciousness of dedication is the core of the Russian national spirit. In the process of cultivating the Russian national spirit, the patriotism spirit has led the cultivation of other national spirits. Whether it is propaganda, religious activities or cultural carriers, especially the space-time carriers with 
realize the Chinese nation's great rejuvenation and dream of China. In order to achieve this goal, the entire nation must be united and work together and that requires ther further development and cultivation of the spirit of the Chinese nation. The national spirit with patriotism as its core is given to the connotation of the new era, and Russia's good practices in the process of cultivating the national spirit are fully borrowed to fully expand the space for the cultivation of the Chinese national spirit in the new era to enrich the cultivation carrier, and improve the cultivation effect. Cultivating the national spirit must not be complacent, but should be reformed and learned from others in order to truly obtain the strong support of the national spirit in the process of the great rejuvenation of the Chinese nation.

\section{REFERENCES}

[1] Kang Ouyang. Collision of Thoughts and Methodological Reference Comparative Study of National Spirit [M]. Beijing: People's Publishing House, 2009:133-176.

[2] B.JI. Solovyev, Zelin Jia, Shubai Li translation. Russian thought [M]. Hangzhou: Zhejiang People's Publishing House, 2000: 18.

[3] Xing Zhao. Patriotism National Spirit and Modern and Contemporary Chinese and Russian Literature [J]. Science and Education Wenhui, 2003 (6).

[4] Xiaochun Liu, Russian National Economy and Reform [M]. Hohhot: Yuanfang Publishing House, 1999: 9.

[5] M. Timofeev. Incomplete project. Moscow, 2000. С.7. (М.Тимофеев. Незавершенный проект. Москва., 2000. С.7.)

[6] Xiaoli Guo, Jingwei Sun. The Structure and Evolution of Russian Messianic Consciousness [J]. Russian Research,2009(2):116-125.

[7] Li Han. Characteristics of Russian Patriotism Education [J]. Education Review, 2010(4): 153-156.

[8] Medvedev called for a search for the origins of public morality in the releaseist traditions of the peoples of Russia www.newsru.com/religy/12mar2009/gossovet.html. (Медведев призвал искать истоки общ ественной морали в релизиозных традициях народов России. www.newsru.com/religy/12mar2009/gossovet.html.)

[9] Xi Jinping. Winning a comprehensive well-off society, winning a great victory in the new era of socialism with Chinese characteristics, and winning a great victory in socialism with Chinese characteristics in the new era. Report at the 19th National Congress of the Communist Party of China [N]. People's Daily, 2017-10-18. combination of national spirit in school education. It is integrated into all course content to achieve implicit guidance, and runs through the learning process of all ages to form a full-scale guidance. The regular participation in military training and other national defense education practice activities during the school stage also effectively promoted the cultivation of the national spirit. In addition, many social groups can organize national spirit-related cultivation activities in a timely manner to effectively supplement the nation spirit education system.

\section{CONCLUSION}

The Russian nation has distinct national characteristics. Excellent spiritual endowment and persistent national consciousness support Russia to proudly stand in the forest of nations in the world. The Chinese nation and the Russian nation have many intersections in the development of world history, and they have also had quite farreaching effects in many periods. At present, the Chinese nation is struggling to 